Acta Technologica Agriculturae 3

Nitra, Slovaca Universitas Agriculturae Nitriae, 2018, pp. 115-118

\title{
VERIFICATION OF SUITABILITY OF SUBSTRATE COMPOSITION FOR PRODUCTION AND QUALITY OF BIOGAS
}

\author{
Viera KAŽIMÍROVÁ*, Ján GADUŠ, Tomáš GIERTL \\ Slovak University of Agriculture in Nitra, Slovak Republic
}

\begin{abstract}
The paper deals with biogas yield production from two co-substrates - sorghum silage mixture of corn silage and crushed potatoes combined with mixture of livestock manure and swine slurry - in a semi-continuous digester under mesophilic conditions. This paper aims to evaluate the suitability of alternative substrates for biogas production under biogas plant operational conditions. In the first experiment, biogas yield was $0.159 \mathrm{Nm}^{3}$ per hour with methane content of $56.96 \%$ vol. In the second experiment, biogas yield was $0.18 \mathrm{Nm}^{3}$ per hour with methane content of $52.95 \%$ vol. Experiments confirmed that both substrates are suitable for biogas production under the given conditions.
\end{abstract}

Keywords: co-substrate; methane content; biogas plant

Carbohydrate feedstock and waste from animal production, especially livestock excrements, represent perfect type of biomass for biogas production. Feedstock composition is one of the major factors that affect the production of biogas (Kelly and Walker, 2000). Therefore, when designing and operating an anaerobic digester, the quantity and characteristics of the feedstock are important and need to be assessed (Sebola et al., 2014). The process of digestion of crop residues requires inclusion of other components, such as liquid excrements, for its initiation. Furthermore, it is highly recommended to add a certain amount of crop residue to livestock excrement in the digestion process. Materials such as manure and slurry are appropriate for biogas production thanks to their homogeneity and the presence of high amount of methanogenic bacteria. These materials do not require the provision of booster vaccination; however, they do show a lower yield of biogas in comparison to alternative substrates.

Co-digestion represents a procedure for an anaerobic processing of multiple different types of biological materials that are jointly added to the basic, major substrate. Anaerobic co-digestion of different organic wastes together can improve nutrient balance, dilute potentially toxic compounds, and subsequently increase the processing capacity and biogas yield (Mahanty et al., 2014). One of the major benefits resulting from co-digestion is the possibility of digestion of several different biomass types, which can be found in the vicinity of the biogas plant, thereby improving the economic efficiency of the plant. Another benefit is the potential for increase in biogas production, or for obtaining biogas with higher methane content (Košík and Gaduš, 2008). Before the substrates are used in plant, it is necessary to perform their assessment in order to determine the suitability of individual biomass materials for co-digestion.
The aim of this paper is to assess alternative substrate suitability for biogas production under biogas plant operational conditions.

\section{Material and methods}

\section{Experimental method}

The experiments were performed in a horizontal reactor with a volume of $5 \mathrm{~m}^{3}$ at the experimental biogas plant facility of the Slovak University of Agriculture in Nitra, locality of Kolínany. The experiments were performed under operational conditions of the biogas plant. The semicontinuous digester was working under the mesophilic conditions at $40 \pm 1{ }^{\circ} \mathrm{C}$.

A homogenisation tank with substrate liquid component is positioned as preceding the reactor. The reactor has automatic dosing of the liquid and solid substrate components. Digester content is fluctuated automatically and at regular intervals, by means of slow-moving stirrer blades. Raw biogas from the digester is accumulated in a small gasholder, from where it is pumped through the gas volume meter into a large gasholder located above the final storage tank. Fig. 1 shows the scheme of the experimental device.

The observed input substrates were selected with their availability in the given region being taken into account. The investigation was performed on two alternative substrates, results of which were consequently compared with reference substrate. This substrate, used also as inoculum to which the alternative substrates were added, comprised a mixture of livestock manure and swine slurry in a volume ratio $1: 4$. After homogenization, a daily dose of $250 \mathrm{~L}$ of substrate was pumped into the experimental digester, with hydraulic retention time in digester of 20 days. 


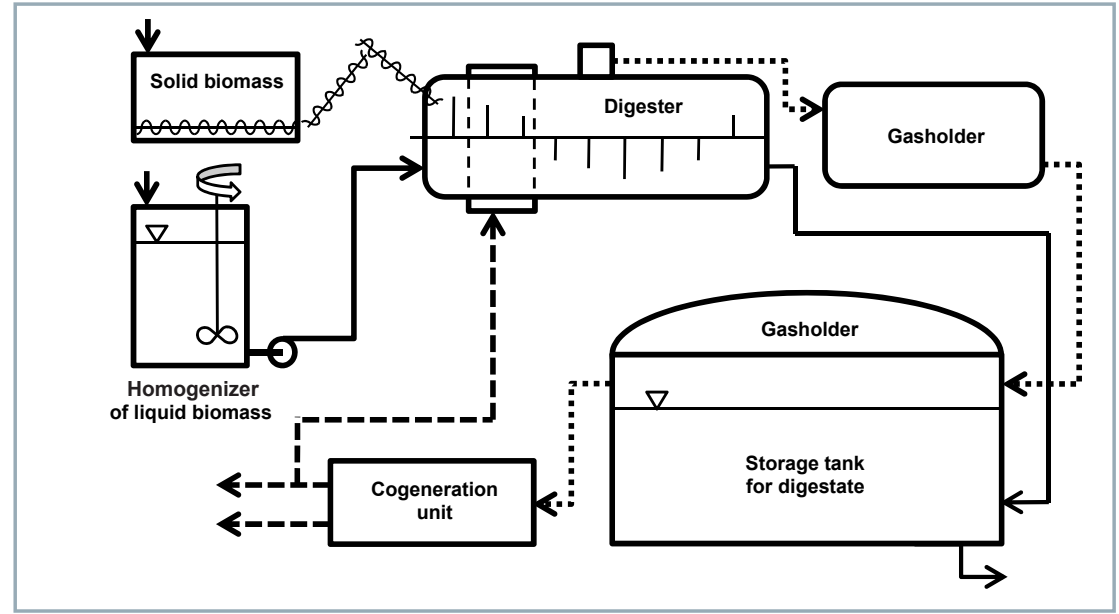

Fig. 1 Scheme of experimental plant

Table 1 Composition of co-substrates

\begin{tabular}{|l|c|c|}
\hline Experiment & Co-substrate & Quantity of co-substrate per day (kg) \\
\hline $\mathbf{1}^{\text {st }}$ & sorghum silage & 15 \\
\hline \multirow{2}{*}{$\mathbf{2}^{\text {nd }}$} & corn silage & 10 \\
& crushed potatoes & 10 \\
\hline
\end{tabular}

In experiments, the same daily substrate dose was utilized, resulting in the identical retention time as for the reference biological material. Volume of the original biomass within digester was decreasing by gradual adding of the daily dose of the observed substrate. Co-substrate in the first experiment consisted of sorghum silage; co-substrate in the second experiment was a mixture of corn silage and ground potatoes, which were unsuitable for food production due to low quality. Composition of the co-substrates is shown in Table 1. Duration of the experiments was 30 days per experiment.

\section{Analytical methods}

The co-substrate composition before digestion process and substrate composition during the digestion process were subjected to analyses in

substrate suitability test for anaerobic digestion. Samples for analyses were prepared by means of dispersant device WTW Disper D8 (Mikro+Polo d.o.o., Slovenia). During the analyses, the content of total solids (TS), chemical oxygen demand (COD), total nitrogen (TN), and sulphate anions $\left(\mathrm{SO}_{4}^{2-}\right)$ was measured.

Samples from digester were tested for the content of total solids (TS), volatile solids (VS), loss on ignition (LOI), ammonium ions $\left(\mathrm{NH}_{4}^{+}\right)$and volatile fatty acids. The $\mathrm{pH}$ values and temperature of substrate in digester were observed during the entire digesting process. Furthermore, the total volume of the produced biogas and amount of individual components were also measured. Other observed parameters included specific biogas production - volume of biogas per volume of digester and per day,

Table 2 Mean values of the observed substrate parameters

\begin{tabular}{|l|c|l||c|}
\hline Parameter & Co-substrate (solid biomass) & Parameter & Digester \\
\hline TS (\%) & 30.94 & TS (\%) & 3.13 \\
\hline COD $\left(\mathbf{g ~ L}^{-1}\right)$ & 153.4 & LOI (\%) & 1.87 \\
\hline TN $\left(\mathbf{m g ~ L}^{-1}\right)$ & 706 & VS $(\%$ of TS) & 82.52 \\
\hline SO $_{\mathbf{4}}\left(\mathbf{m g ~ L}^{-1}\right)$ & 595.6 & $\mathbf{N H}_{\mathbf{4}}\left(\mathbf{m g ~ L}^{-1}\right)$ & 10.2 \\
\hline OLR $\left(\mathbf{k g ~ C O D ~ ~}^{-\mathbf{3}} \mathbf{~ d}^{-1}\right)$ & 3.2 & VFA $\left(\mathbf{m g ~ L}^{-1}\right)$ & 640 \\
\hline
\end{tabular}

TS - total solids; VS - volatile solids; LOI - loss on ignition; COD - chemical oxygen demand; $\mathrm{TN}$ - total nitrogen; $\mathrm{NH}_{4}^{+-}$- ammonia; $\mathrm{SO}_{4}^{2-}$ - sulphate; $\mathrm{OLR}$ organic loading rate; VFA - volatile fatty acids methane content $\left(\mathrm{CH}_{4}\right)$, and other biogas components $\left(\mathrm{CO}_{2}, \mathrm{O}_{2}\right.$ and $\left.\mathrm{H}_{2} \mathrm{~S}\right)$.

TS test was carried out by constant weight drying method. TS were measured by moisture analyser Kern MLB 50-3 (Kern \& Sohn GmbH, Germany). $\mathrm{COD}$, total $\mathrm{N}, \mathrm{SO}_{4}^{2-}, \mathrm{NH}_{4}^{+}$were measured photometrically by means of the standard methods by PhotoLab S12 (Xylem Analytics Germany Sales GmbH \& Co. KG, WTW, Germany). Gas analyser Schmack SSM 6000 (Schmack Biogas AG, Germany) was utilized for gas composition assessment; for measurement of $\mathrm{H}_{2} \mathrm{~S}$ and $\mathrm{O}_{2}$ electrochemical sensor was utilized and values of $\mathrm{CH}_{4}$ and $\mathrm{CO}_{2}$. Biogas yield was measured by means of membrane gas meter BK-G2.5M (Elster $\mathrm{GmbH}$, Germany). Biogas yield was converted to units of $\mathrm{Nm}^{3}$ in accordance with the standards given by ISO 6979:2016.

\section{Results and discussion}

\section{$1^{\text {st }}$ experiment}

The results of the analyses are given in Table 2.

Content of dry matter in sorghum silage is $30.94 \%$. For bacteria to be able to degrade the material, the dry matter content must not be higher than around $50 \%$. In a biogas plant, however, it should only be around $8-10 \%$, if it is to remain liquid enough to be pumped (Jørgensen, 2009). Due to this, the silage was dosed by means of a direct line. The mean COD of sorghum silage was $153.4 \mathrm{~g} \mathrm{~L}^{-1}$ and total nitrogen amount was $706 \mathrm{mg} \mathrm{L}^{-1}$. Organic loading rate was $3.19 \mathrm{~kg} \mathrm{COD} \mathrm{m}^{-3} \mathrm{~d}^{-1}$.

The substrate composed of manure, slurry and sorghum silage showed dry mass content in digester at $3.13 \%$ and value of organically decomposable dry matter at $82.52 \%$ of TS.

Fig. 2 shows the measured content of biogas components on individual days. The oxygen content within each biogas sample was zero throughout the entire experiment.

Throughout the test cycle, the methane content of the biogas was highly stable and reached an average of $56.96 \%$ vol. Very positive values were also achieved with hydrogen sulphide $83.3 \mathrm{ppm}$ on average - resulting in unnecessity of further biogas treatment before application to the cogeneration unit. Average $\mathrm{CO}_{2}$ content was $41.6 \%$ vol. 
Fig. 3 shows biogas yield, temperature and $\mathrm{pH}$ values measured on each day of experiment.

Biogas yield was not stable during the experiment period. It was decreasing at the beginning of the experiment, with minimum biogas yield value observed on the $8^{\text {th }}$ day; followed by subsequent increase and maximum biogas yield value observed on the $26^{\text {th }}$ day. The average of biogas yield was $0.159 \mathrm{Nm}^{3}$ per hour, the average temperature in digester was $38.11^{\circ} \mathrm{C}$ and the average $\mathrm{pH}$ was 7.18. Temperature and $\mathrm{pH}$ of substrate were constant during the entire experiment.

\section{$2^{\text {nd }}$ experiment}

The mean values of the observed parameters are given in Table 3.

These values demonstrate that the substrate in the digester has shown a satisfactory VS value $-73.72 \%$ of TS. The samples of solid biomass before

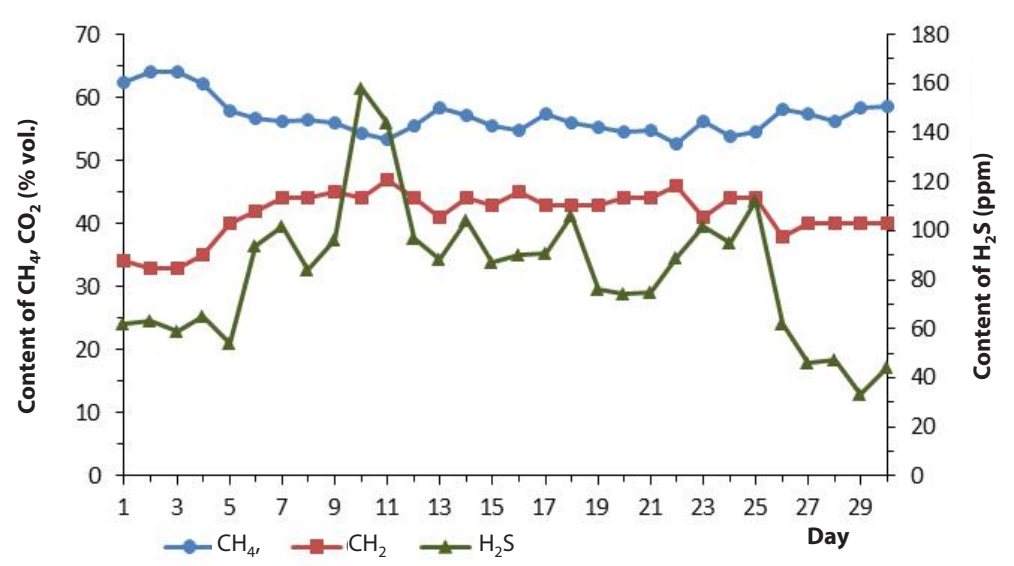

Fig. 2 Content of $\mathrm{CH}_{4}, \mathrm{CO}_{2}$ and $\mathrm{H}_{2} \mathrm{~S}$ in biogas

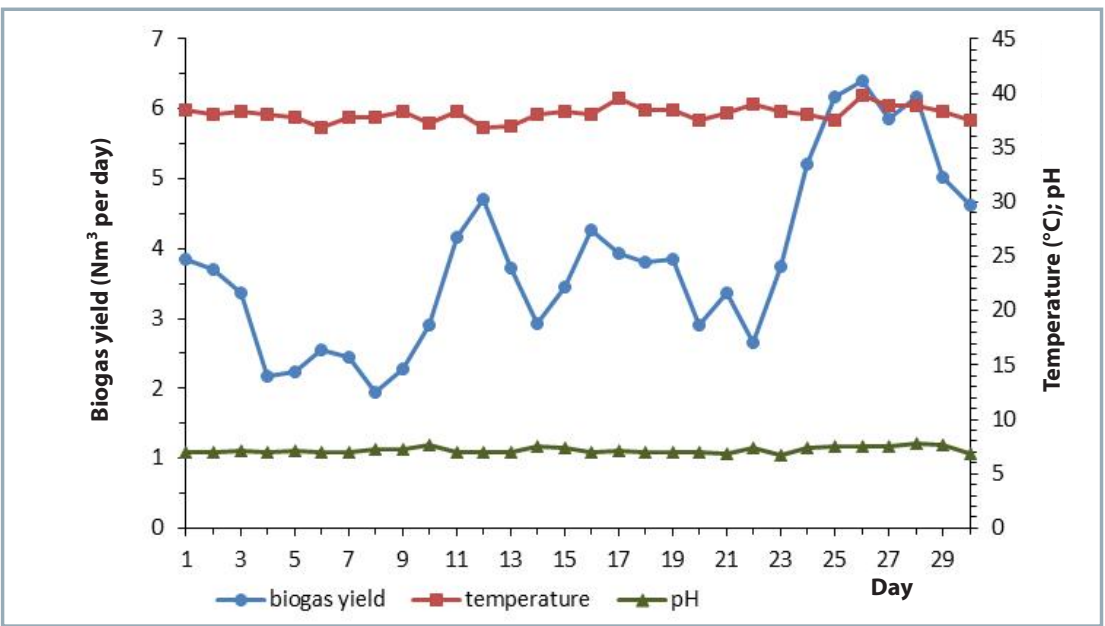

Fig. 3 Biogas yield, temperature and $\mathrm{pH}$ values

Table 3 Mean values of the observed substrate parameters

\begin{tabular}{|c|c|c|c|}
\hline Parameter & Co-substrate (solid biomass) & Parameter & Digester \\
\hline TS (\%) & 25.6 & TS (\%) & 2.7 \\
\hline $\operatorname{COD}\left(\mathrm{g} \mathrm{L}^{-1}\right)$ & 21.74 & LOI (\%) & 1.74 \\
\hline $\mathrm{TN}\left(\mathrm{mg} \mathrm{L}^{-1}\right)$ & 32.2 & VS (\% of TS) & 73.72 \\
\hline $\mathrm{SO}_{4}\left(\mathrm{mg} \mathrm{L}^{-1}\right)$ & 39.2 & $\mathrm{NH}_{4}\left(\mathrm{mg} \mathrm{L}^{-1}\right)$ & 6.7 \\
\hline OLR (kg COD m $\left.\mathrm{m}^{-3} \mathrm{~d}^{-1}\right)$ & 0.45 & VFA $\left(\mathrm{mg} \mathrm{L}^{-1}\right)$ & 414 \\
\hline
\end{tabular}

feeding to digester showed mean COD value of $21.74 \mathrm{~g} \mathrm{~L}^{-1}$.

TS content in substrate was very low during the experiment - $2.7 \%$ on average; therefore, it would be possible to increase the daily dose of the investigated substrate fourfold in order to achieve more efficient digester utilisation. Furthermore, the low value of OLR indicates the possibility of increasing the co-substrate dose; however, higher production of biogas is not always achieved at a large OLR.

Fig. 4 shows the measured content of biogas components on individual days. The oxygen content of the biogas was zero throughout the entire experiment.

In the second investigated co-substrate, the average methane content in the biogas was $52.95 \%$ vol.; however, hydrogen sulphide value was higher - 210.1 ppm on average, meaning that this biogas would require desulphurization in order to decrease the value below 100 ppm before usage in the cogeneration unit. The average $\mathrm{CO}_{2}$ content in biogas was $47 \%$ vol.

Fig. 5 shows biogas yield, temperature and $\mathrm{pH}$ values measured on each day of experiment.

Average of biogas yield was 0.18 $\mathrm{Nm}^{3}$ per hour. Value of $\mathrm{pH}$ was stable, average $\mathrm{pH}$ of substrate in digester was 6.93 , which is slightly lower than values recommended by Jørgensen (2009), who reports that the most suitable $\mathrm{pH}$ for methane production is 7.2. The temperature in the digester was stable, with an average of $38.39^{\circ} \mathrm{C}$.

The comparison of the obtained mean content values of methane, hydrogen sulphide, $\mathrm{CO}_{2}$, and biogas yield in both experiments with the reference substrate is given in Table 4.

The specific biogas production was 5.37 times higher in the first experiment and 5.82 times higher in the second experiment in comparison to reference substrate, which represents a significant result. The differences in the amount of the produced biogas are significant despite the lower methane content. Similarly to research performed by Alvarez and Lidén (2008), Dubrovskis and Plume (2017), Luna-del Risco et al. (2011), our results also confirm that the increase in biogas production can be achieved by means of an appropriate combination of materials. 


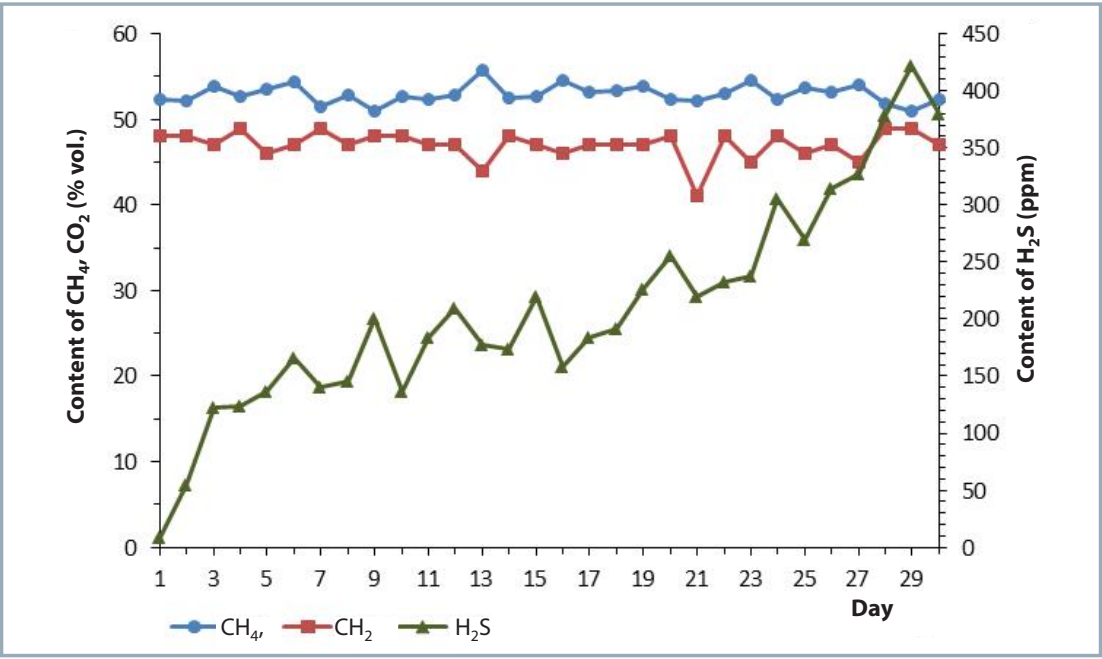

Fig. 4 Content of $\mathrm{CH}_{4}, \mathrm{CO}_{2}$ and $\mathrm{H}_{2} \mathrm{~S}$ in biogas

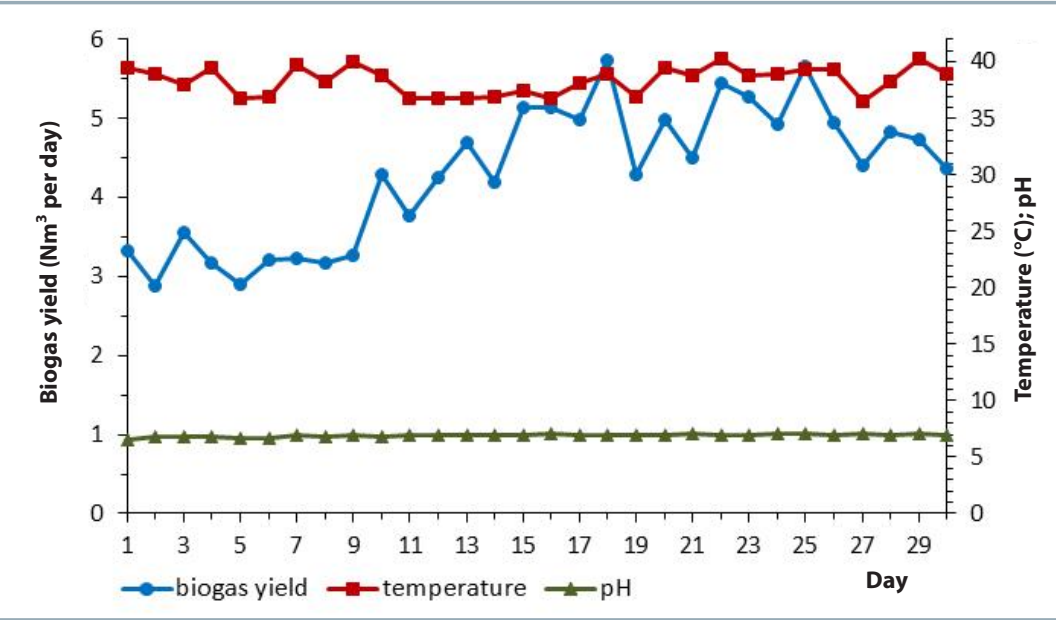

Fig. 5 Biogas yield, temperature and $\mathrm{pH}$ values

Table 4 The comparison of mean parameters of biogas production

\begin{tabular}{|l||c|c|c|c|c|}
\hline Substrate & $\begin{array}{c}\mathbf{C H}_{\mathbf{4}} \\
\text { (\% vol.) }\end{array}$ & $\begin{array}{c}\mathbf{H}_{\mathbf{2}} \mathbf{S} \\
(\mathbf{p p m})\end{array}$ & $\begin{array}{c}\mathbf{C O}_{\mathbf{2}} \\
(\mathbf{\%} \text { vol.) }\end{array}$ & $\begin{array}{c}\text { Biogas yield } \\
\left(\mathbf{N m}^{\mathbf{3}} \mathbf{h}^{-1}\right)\end{array}$ & $\begin{array}{c}\text { Biogas specific } \\
\text { yield } \mathbf{( m}^{\mathbf{3}} \mathbf{~ m}^{-3} \\
\mathbf{d}^{-\mathbf{3}} \mathbf{)}\end{array}$ \\
\hline \hline $\mathbf{1}^{\text {st }}$ experiment & 56.96 & 83.3 & 41.6 & 0.159 & 0.859 \\
\hline $\mathbf{2}^{\text {nd }}$ experiment & 52.95 & 210.1 & 47 & 0.18 & 0.931 \\
\hline $\begin{array}{l}\text { Reference/ } \\
\text { comparative substrate }\end{array}$ & 60.8 & 1,343 & 31.2 & 0.032 & 0.16 \\
\hline
\end{tabular}

$\mathrm{CH}_{4}$ - methane, $\mathrm{H}_{2} \mathrm{~S}$ - hydrogen sulphide, $\mathrm{CO}_{2}$ - carbon dioxide; $\mathrm{Nm}^{3}$ - normal cubic meter

The mean hydrogen sulphide content, which is considered an undesirable component of biogas, is significantly lower than in case of reference substrate.

\section{Conclusion}

The obtained results have confirmed the suitability of usage of sorghum silage, potatoes and corn silage as a co-substrate in biogas devices.
The reduced production of hydrogen sulphide content in the first experiment is a phenomenon that cannot be neglected, since hydrogen sulphide is undesirable due to its corrosive impacts, especially when using biogas in cogeneration units.

The experimental results confirm that it is essential to pay adequate attention to suitability verification of substrates before practical utilization in biogas stations, as well as efforts to seek biodegradable materials for digestion that are available in sufficient quantities at a reasonable cost.

\section{References}

ALVAREZ, R. - LIDÉN, G. 2008. Semicontinuous co-digestion of solid slaughterhouse waste, manure, and fruit and vegetable waste. In Renewable Energy, vol. 33, no. 4, pp. 726-734.

DUBROVSKIS, V. - PLUME, I. 2017. Biogas from wastes of pumpkin, marrow and apple. In Agronomy Research, vol. 15, no. 1, pp. 69-78.

JØRGENSEN, P. J. - PlanEnergi. 2009. Biogas - Green Energy. Aarhus : Aarhus University 36 pp. ISBN 978-87-992243-2-1.

KELLY, T. - WALKER, P. 2000. Bacterial concentration reduction in swine waste amended livestock feed using a singlescrew dry-extrusion process, In Bioresource Technology, vol. 75, no. 3, pp. 189-195.

KOŠíK, L. - GADUŠ, J. 2008. Biogas from anaerobic co-fermentation of cattle slurry and maize silage after mechanical pre-treatment of substrate. In Acta Technologica Agriculturae, vol. 11, no. 4, pp. 105-109. (in Slovak: Bioplyn z anaeróbnej kofermentácie hnojovice s kukuričnou silážou po mechanickom predspracovaní substrátu).

LUNA-DEL RISCO, M. - NORMAK, A. ORUPÕLD, K. 2011. Biochemical methane potential of different organic wastes and energy crops from Estonia. In Agronomy Research, vol. 9, no. 1-2, pp. 331-342.

MAHANTY, B. - ZAFAR, M. - HAN, M. J. - PARK, H. S. 2014. Optimization of codigestion of various industrial sludges for biogas production and sludge treatment: Methane production potential experiments and modelling. In Waste Management, vol. 34, no. 6, pp. 1018-1024.

SEBOLA, R. - TESFAGIORGIS, H. B. MUZENDA, E. 2014. Production of biogas trough anaerobic digestion of various waste: review. In Internatinal Conference on Chemical, Integrated Waste Management \& Environmental Engineering. Johannesburg: University of Johannesburg, pp. 196-201. 